\title{
The Effect of 'Excessive' Tax Planning and Tax Setting on Welfare: Action Needed?
}

\author{
Hendrik Vrijburg*
}

\begin{abstract}
This article presents a literature review on the welfare effects of excessive company taxation practices. The article intends to structure the debate by sketching a conceptual framework of thought for the topic under consideration and places the existing literature within this framework. The article ends with a thought-provoking discussion between two extreme papers in the literature, one against tax planning and one in favour. The discussion is concluded by identifying the fundamental differences in assumptions underlying both approaches.
\end{abstract}

Keywords: tax planning, optimal taxation, tax competition, corporate taxation

\section{Introduction}

Excessive company taxation practices are again being intensely discussed in the public debate. Recently, there have been hearings of the CEOs of a number of Multinational Enterprises (MNEs) in the United Kingdom (e.g., Starbucks, Google and Amazon) and the United States (Apple). ${ }^{1}$ In the Netherlands, the political parties in the opposition are fulminating against the practice of MNEs using fiscal detours through the Netherlands to reduce their effective tax bill. Furthermore, the European Commission (EC) and the OECD have taken up their attempts to fight such harmful tax practices. ${ }^{2}$ This public attention is not new; it tends to pop up every few years. After some time, journalists will start to complain about the low effective tax bill of MNEs, and in their aftermath, politicians and some opinion leaders are upset, which in turn upsets the voters (or in some other order). Unfortunately, an overall view, including a consistent conceptual framework, is missing in almost all these discussions, leading to unfortunate conclusions. This article is devoted to the question of whether, from the perspective of an economist, supranational cooperation is needed to stop 'excessive company taxation prac-

* Assistant Professor, Erasmus School of Economics, Erasmus University Rotterdam and Tinbergen Institute, PO Box 1738, 3000 DR Rotterdam, The Netherlands, Phone: +31-10-408-1485, Fax: +31-10-408-9031, email: vrijburg@ese.eur.nl.

1. See on the website of the BBC the article titled 'Starbucks, Google and Amazon Grilled over Tax Avoidance', and the article 'Koffieketen Starbucks Zwicht', Het Financieel Dagblad, 7 December 2012.

2. See for example the Report of the European Council of 23 May 2013. tices' within the European Union (EU). In this context, the phrase 'excessive company taxation practices' is related to both the tax-planning activities of firms and preferential tax setting by tax authorities. I aim to achieve two goals with this article. First, the article discusses the main conclusions in the economic literature on the topic. Given the numerous papers that are written on this matter, this review is not complete, and the discussion is therefore intended to give an overview of the topics covered. ${ }^{3}$ Second, and most importantly, a conceptual framework of thought is developed that helps to structure the debate on excessive company taxation practices. The conceptual framework is used to clarify some of the inconsistencies in the public debate and to place the scientific articles discussed within a broader context.

This article does not assess whether it is possible at all to remove excessive company taxation practices, and whether government action in this direction has been successful. ${ }^{4}$ Instead, I begin one step earlier, raising the question of whether such measures should be undertaken at all. This being the objective, the article will not discuss the empirical evidence on excessive company taxation. Although equally important, welfare losses are computed with the use of empirical estimates of the statistics that are suggested by a proper welfare analysis, this article will focus on the latter topic. In general, empirical evidence confirms the responsiveness of capital flows to taxation. ${ }^{5}$ In addition, an interesting recent

3. Excellent review papers on the tax competition literature are J.D. Wilson, 'Theories of Tax Competition', 52 National Tax Journal, at 269-304 (1999); G.R. Zodrow, 'Tax Competition and Tax Coordination in the European Union', 10 International Tax and Public Finance, at 651-671 (2003); J.D. Wilson and D.E. Wildasin, 'Capital Tax Competition: Bane or Boon?', 88 Journal of Public Economics, at 1065-1091 (2004); G. Nicodeme, 'Corporate Tax Competition and Coordination in the European Union: What Do We Know? Where Do We Stand?', MPRA Working Paper No. 107 (2006); and recently M. Keen and K.A. Konrad, 'International Tax Competition and Coordination', Max Planck Institute for Tax Law and Public Finance Working Paper No. 2012-06 (2012).

4. See for example M. Ruf and A.J. Weichenrieder, 'The Taxation of Passive Foreign Investment: Lessons from German Experience', 45 Canadian Journal of Economics, at 1504-1528 (2012), who show that it might indeed be possible to tax passive income abroad.

5. Some excellent review articles that cover the most important papers in the empirical literature are: D. Dharmapala, 'What Do We Know about Base Erosion and Profit Shifting? A Review of the Empirical Literature', CESifo Working Paper No. 4612 (2014); R.A. De Mooij, 'The Tax Elasticities of Corporate Debt: A Synthesis of Size and Variations', IMF Working Paper WP/11/95 (2011); and R.A. De Mooij and S. Ederveen, 'Taxation and Foreign Direct Investment: A Synthesis of Empirical Research', 10 International Tax and Public Finance, at 673-693 (2003). 
insight is that the magnitude of base erosion and profit shifting (BEPS) is typically smaller in recent studies compared with older research. ${ }^{6}$

The article provides some counter-intuitive insights to the uninformed reader as I will claim below that obtaining revenue from multinationals is not a valid policy objective and that tax planning might, in some circumstances, actually be welfare improving. This stands in sharp contrast to the simple and clear solutions to excessive company taxation practices suggested in the public debate (making public the tax payments of MNEs, closing all tax loopholes, European cooperation). The cause of this confusion is the complexity of the topic and insufficient knowledge of the economics of taxation by the general public. Instead, politicians often use simple heuristics as an intuitive guide to a supposed optimal tax policy. However, these intuitive suggestions can be considerably flawed. The price of following those could be substantial.

Note that the generality of the question posited requires a general analysis. Without going into the details of the corporate tax system, apart from the well-known characteristics, I only address the greater picture, bypassing all specific inaccuracies in the design of our current corporate tax system as well as the existing differences between national tax systems. Unless otherwise mentioned, I presuppose in what follows that all countries have a classical corporate tax system where only interest on debt is tax deductible and foreign earnings are, in the most optimistic case, taxed at a substantially lower effective tax rate compared with domestically earned income. This simplification holds for most papers in the tax competition literature, in which it is assumed that governments are restricted to using source-based capital income taxes. Within such a system, tax planning can be achieved by smart use of transfer-pricing rules or complicated financial structures or both. These practices will not be discussed in detail here. Also, I use the terms 'evasion' and 'avoidance' interchangeably, as from an economic point of view there is only a thin line between legal and illegal use of the tax law to lower one's tax bill.

The rest of the article discusses a number of steps that can be taken in an attempt to answer the question of what the welfare costs are of excessive company taxation practices. To start with, in Section 1, I discuss the crucial issue of the alternative tax system with which the current system should be compared. To get an idea about welfare costs, we need to structure our thoughts about the 'best' possible alternative. This is the first blank spot in the current policy discussion. Unfortunately, the economic literature also is, to my knowledge, still searching for the correct benchmark. Note the importance of this point to the answer of the research question posited at the start of this article. When the best alternative changes shape, the welfare costs change one-for-one. Thereafter, in Section 2, I discuss the classical tax competition literature because the most prominent conclusion from this literature, a race to the bottom

6. See Dharmapala, above n. 5 . in company taxes, echoes in the public debate. Section 3 discusses a number of studies that have tried to quantify the arguments raised in the classical tax competition literature. Thereafter, Section 4 is devoted to a recent development in the tax competition literature that might turn the debate upside down. Finally, Section 5 concludes the discussion with some modest advice for policymakers.

\section{With What Should Our Current Tax System Be Compared?}

Before I can put a number on the welfare costs of excessive behaviour, if it is possible at all, I need to discuss the alternative with which we should compare our current tax system. In other words, what is the optimal feasible corporate tax system? Such a discussion is very important as this is where the confusion between economists and the public originates.

First, the reader should remember that part of the research effort of tax economists is invested in answering the question of how the government should design its tax system such that public goods can be financed, after-tax income is distributed equitably and the economy is distorted as little as possible. The latter statement implies that, in the absence of market failures, the government should try to minimise the influence of taxes on individual choices. ${ }^{7}$ Second, economists regard firms as being a (paper) representation of cooperation among individuals. This leads to the insight that in the end not firms but natural individuals pay taxes. ${ }^{8}$ Both issues are crucial in the following discussion.

Economic analyses of tax systems can be categorised by the assumptions that are made on the information set available to the government. ${ }^{9}$ In the so-called first-best, the government has perfect information. The government observes an individual's earnings ability (or inherent talent), the actual income earned, how this income is distributed over capital and labour, how the income is spent and how the earnings ability is distributed over society. This assumption makes the optimal equitable tax system in the first-best very simple. The government can just let each individual pay tax according to

7. See for an introduction into the discussion in this section amongst others various chapters in J.E. Stiglitz, Economics of the Public Sector (1999)

8. See amongst others A.J. Auerbach, 'Who Bears the Corporate Tax? A Review of What We Know', 20 Tax Policy and the Economy, at 1-40 (2005)

9. The optimal corporate tax system is also discussed in pp. 876-869 in A.J. Auerbach, M.P. Devereux \& H. Simpson, 'Taxing Corporate Income', in J.A. Mirrlees et al. (eds.), The Mirrlees Review. Dimensions of Tax Design, ch. 9 (2010), at 837-913; R. Griffith, J. Hines \& P.B. Sørensen, 'International Capital Taxation', in Mirrlees et al., see above, ch. 10, at 914-1027; and J. Mintz, 'The Corporation Tax: A Survey', 16 Fiscal Studies, at 23-68 (1995). Furthermore, R. de Mooij, 'Will Corporate Income Taxation Survive', 153 De Economist, at 277-301 (2005), also mentions redistribution as an argument for corporate taxation. 
his or her (observed) ability to earn income, in such a way that public goods can be financed and the distribution of after-tax income is equitable. Note that this hypothetical tax bill is exogenous to the individual (a socalled individualised lump sum transfer) and does not depend on choices made by the individual; it is like the talent-tax proposed by Jan Tinbergen. ${ }^{10}$ Such a tax system, although it might seem immoral to some readers, would not cause any distortions to the economy and would reduce income inequality next to providing finance for public goods.

Although highly stylised, this first-best is an interesting benchmark: when individual earnings ability can be taxed optimally, there is no role for the corporate tax, and hence no welfare costs of excessive company taxation practices. The government can redistribute and finance all it desires and therefore does not need to use a corporate tax, which is regarded as highly distortionary because of its influence on for example investments. ${ }^{11}$ The first-best also reveals a second important lesson: in 'simple' economic models, it is never a goal of government policy to tax firms for revenue. Here, 'simple' is used in the sense that there are no market failures that lead to an argument for Pigouvian taxes and assuming there are no administrative cost savings achievable from taxing firms instead of individuals. The latter can surely be an argument for an indirect tax on individuals via firms. ${ }^{12}$ Some might argue that it might be optimal to use a corporate tax because part of the incidence is on immobile rents. However, immobile rents are, by definition, related to a location such that the government could use a local property tax as well for such a policy goal.

Now let us constrain the information set of the government. Economists define the second-best as the case where the government cannot observe all relevant characteristics of an individual's ability to earn income. Instead, it observes the next best thing: individual income from capital and labour. Before moving on, I must stress that I assume in the rest of the article that taxing individual capital income is in principle desirable and helpful in redistributing income. There is a huge literature on this topic that I do not want to repeat

10. J. Tinbergen, 'Belasting op Bekwaamheid', 30 Intermediair, at 1-3 (1970).

11. See for evidence on the economic distortions of the corporate tax: A Johansson, C. Heady, J. Arnold, B. Brys \& L. Vartia, 'Taxation and Economic Growth', OECD Economics Department Working Paper (2009). In the text, I ignore arguments for taxing foreigners with the corporate tax for simplicity. In this simple set-up, and assuming capital is perfectly mobile, the government can only impose and enforce a lump sum tax on foreigners when the resulting after-tax average rate of return upon investing in the country is not below the after-tax average return that can be obtained abroad.

12. See for an excellent discussion for example pp. 876-869 in Auerbach et al., above n. 9 . here. ${ }^{13}$ When capital income should not be taxed at all, the case for the corporate tax is obviously very weak.

Let us focus, therefore, on the case where individual capital income should be taxed. When the government can tax both individual capital and labour income, it is hard to see why a corporate tax is needed at all. The resulting residence-based capital tax system has the attractive feature that it leaves the allocation of investment unaffected: it would result in capital export neutrality. This is because for the investor it does not matter where in the world its money is invested, the effective tax rate is always the domestic personal tax rate. ${ }^{14}$ In such a setting, a corporate tax might be optimal only when we can think of cases where the profits of firms give a credible signal of the earnings ability of the underlying (domestic) investors, which is different from the signal obtained from their capital income itself - for example, when high-ability individuals invest (partly) in better-performing firms and this effect is not already accounted for by taxing the higher capital incomes (one can imagine that a linear tax on capital income cannot perfectly tax a hypothetical optimal non-linear capital earnings profile). Only in such a case might the corporate tax help in redistributing income. I have not come across such an analysis in the literature yet. In most studies, investment portfolios are assumed to be perfectly diversified such that everybody earns the same average return. To conclude, it is difficult to see why a corporate tax, next to a normal tax on capital income, would be needed in the second-best, and hence excessive tax planning does not reduce welfare apart from the resources used for this practice.

But most economists and tax lawyers will agree that even this second-best is not realistic. Two arguments can be given. First, the government does not have sufficient information to verify the capital income that all its citizens earn somewhere in the world, that is, it cannot effectively tax all capital income at the personal level. When the opportunity to evade or avoid the capital income tax is correlated with the ability to pay taxes, and investors prefer to invest at least some of their income in their home country, the corporate tax as a withholding tax assists in achieving equity. It makes sure that at least the income earned at source is (partly) taxed before it has the opportunity to be shifted around the world.

The qualifying conditions here are interesting by themselves. When all individuals evade and avoid to the same relative extent, it is not entirely clear that a corporate tax is helpful in redistributing income. With respect to the second qualifying condition, we need that at least some

13. See amongst others G.N. Mankiw, M. Weinzierl \& D. Yagan, 'Optimal Taxation in Theory and Practice', 23 Journal of Economic Perspectives, at 147-174 (2009); P.A. Diamond and E. Saez, 'The Case for a Progressive Tax: From Basic Research to Policy Recommendations', 25 Journal of Economic Perspectives, at 165-190 (2011); J. Banks and P.A. Diamond, 'The Base for Direct Taxation', in Mirrlees et al., above n. 9, ch. 6, at 548-648; and B. Jacobs, 'From Optimal Tax Theory to Applied Tax Policy', 69 Finanz Archiv, at 338-389 (2013), for an introduction into this discussion.

14. See for a discussion pp. 923-929 in Griffith et al., above n. 9. 
of the more able invest in their home country, otherwise there will be nothing to redistribute. However, one might claim that the revenues from foreigners serve as a good substitute in case all rich citizens invest abroad. At the other extreme, when all individuals invest at home, a correctly designed withholding tax on corporate income is equivalent to a personal capital tax and is therefore a good instrument to redistribute income.

A second argument for the corporate tax is that the government does not have sufficient information to perfectly distinguish between labour income and capital income for certain individuals. Therefore, the corporate tax systems of most countries try to equalise the net tax burden of small incorporated firms with the tax burden that the owners would face when they would not be incorporated. This is labelled the 'backstop function' of the corporate tax system. When the corporate tax is absent, everybody can try to find a way to be defined as a corporation for the tax law, leading to an erosion of the $\operatorname{tax}$ revenue, and the redistributive function of the income tax system. ${ }^{15}$

Both considerations, the corporate tax assists in redistribution and serves as a 'backstop,' are fundamental to the discussion in this article because they make clear that the corporate tax is important only because the government is constrained in the information it has concerning the ability to pay of its citizens. To my knowledge, only a limited number of papers have addressed the imperfect information aspect of corporate taxation. ${ }^{16}$ Furthermore, the discussion stresses that the only argument for having the corporate tax is equity. In my opinion, all models not including these issues should be interpreted with care. As we will discover further on, this implies that only a few papers in the literature give us some guidance in figuring out the welfare costs of excessive company taxation practices. And these few papers do not provide a clear and coherent view. ${ }^{17}$

Note that even when the reader believes that the above discussion is only semantic such that one can simply bypass the philosophical question as to why we need a corporate tax and that only revenue from firms matters, he or she should realise that even in this case it might be optimal to differentiate the tax system between mobile

15. See amongst others A.J. Weichenrieder, '(Why) Do We Need Corporate Taxation?', CESifo Working Paper No. 1495 (2005); and R.A. de Mooij and G. Nicodeme, 'Corporate Tax Policy and Incorporation in the European Union', 15 International Tax and Public Finance, at 478-498 (2008)

16. See P. Osmundsen, K.P. Hagen \& G. Schjelderup, 'Internationally Mobile Firms and Tax Policy', 45 Journal of International Economics, at 97-113 (1995); and J. Becker and C. Fuest, 'Optimal Tax Policy When Firms Are Internationally Mobile', 18 International Tax and Public Finance, at 580-604 (2011).

17. Other arguments sometimes mentioned are that the corporate tax can be used to export part of the tax burden and that it serves as a 'benefittax'. The former argument is certainly important from a unilateral point of view, but can hardly be seen as optimal from a global welfare-maximising point of view. The latter argument is dismissed by Weichenrieder, above n. 15 and Mintz, above n. 8. Mintz rightly claims that: '[...] there are often other better targeted instruments available for internalizing the cost of providing public inputs'. Both arguments are therefore not further pursued here. See Weichenrieder, above n. 16; and Mintz, above n. 8, at 23-68. and immobile firms, ${ }^{18}$ where the mobile firms should be taxed at a substantially lower rate than immobile firms. This is an application of the Ramsey inverse elasticity rule. The immobility signals that individuals are not willing or able to circumvent the tax and, hence, the economic distortion caused by such a tax is rather low: the immobile firms will remain in the same location, supply a similar quantity of products and demand a similar quantity of production factors. See Section 5 for a further discussion.

\section{The Classical Tax Competition Model: Where Is the Tax Planning?}

Having introduced the economics of the corporate tax, we can now continue with discussing the classical tax competition literature. Following the seminal works of C.M. Tiebout, W.E. Oates and many others, the classical tax competition model was established in a number of articles in the mid-1980s by some influential writers like P. Mieskowsky, J.D. Wilson and G.R. Zodrow. ${ }^{19}$ In this model it is assumed that there exist a number of identical countries populated with citizens who are also all identical. ${ }^{20}$ These citizens work within the firms in the country, and they invest all their capital in the international capital market, implying that capital is (perfectly) mobile across countries. The firms are also all identical. The governments are assumed to tax this capital income at source to obtain sufficient tax revenue for the financing of the public good that their citizens desire. Note that when capital is taxed, it will leave the country until the point where the demand for capital in the country has increased by enough to generate after-tax returns that are equivalent to the return that can be earned abroad. Typically, it is assumed that the capital tax is the only tax instrument that the government possesses; it cannot use lump sum transfers but is forced to use the distortionary source-based tax on capital. As mentioned before, such lump sum transfers are simple unconditional payments from the citizens to the government, unconditional meaning that the payment does not depend on individual choices. Such lump sum transfers

18. See M. Keen, 'Preferential Regimes Can Make Tax Competition Less Harmful', 54 National Tax Journal, at 757-762 (2001). This topic is more fully discussed at the end of the article.

19. See for classical references J.D. Wilson, 'A Theory of Interregional Tax Competition', 19 Journal of Urban Economics, at 296-315 (1986); and G.R. Zodrow and P. Mieszkowsky, 'Pigou, Tiebout, Property Taxation, and the Underprovision of Local Public Goods', 19 Journal of Urban Economics, at 356-370 (1986). Excellent reviews of the literature are given in Wilson, above n. 3; Zodrow, above n. 3 and Keen and Konrad, above n. 3.

20. Please realise that economists are aware of the simplicity of such an assumption. The goal is not to be entirely accurate but to make the model simple enough to only capture the essence of a discussion such that arguments can be checked for logical consistency. Later on, a model can be adjusted to include additional arguments that might be important. 
are a superior financing instrument. Allowing the government in the model to use it would imply zero optimal capital taxes. Instead, the government in the model is forced to use the distortionary capital tax in such a way that the welfare of its own citizens is maximised. ${ }^{21}$ This assumption implies that the tax imposes a positive externality upon other countries: if the tax is increased, capital flows to neighbouring countries, yielding both extra tax revenues and higher wages abroad. The home government does not take this positive effect of a tax increase into account. Hence, as is always the case with positive externalities, governments decide on a tax rate that is too low from a global welfare point of view, and subsequently all countries together have tax revenues and public expenditures that are too low from a global welfare point of view. The smaller the country, or the more countries in the world, the lower the tax rate. ${ }^{22}$ This is the first crucial characteristic of classical tax competition models; tax rates and public revenues are too low owing to the existence of this positive spillover.

If Europe were such a simple world, everybody would be made better off by EU-wide cooperation. However, this positive effect of cooperation is unambiguous only under the assumption of symmetry. Complications arise when the model is extended. First, when asymmetries between countries are introduced, for example differences in size, some countries tend to gain (the large countries) and others tend to lose from cooperation (the small countries). ${ }^{23}$ Next to size, countries might also differ in for example endowments or productivity. ${ }^{24} \mathrm{On}$ the other hand, when asymmetries between countries exist, tax competition tends to distort the allocation of capital between countries. This implies that tax coordination has the potential for improving welfare by improving the allocation of capital across countries. Second, note that in the equilibrium of a symmetric classical tax competition model, there are no net capital importers or exporters: the symmetry between the countries implies that all governments choose exactly the same tax rate, so there is no reason to invest abroad. When in richer models cross-ownership of assets occurs,

21. Some papers do not pay attention to public goods and welfare, see for example R. Kanbur and M. Keen, 'Jeux Sans Frontieres: Tax Competition and Tax Coordination when Countries Differ in Size', 83 American Economic Review at 877-892 (1993); these studies simply assume that the government wants to maximise its own tax revenues. We will see later that this makes a great difference in evaluating optimal tax policy. Also, it is crucial to note that the government cares about its own payoff alone; if the government cared about the payoff of other countries, tax competition would be less of a problem.

22. See amongst others W. Hoyt, 'Property Taxation, Nash Equilibrium and Market Power', 30 Journal of Urban Economics, at 123-131 (1991).

23. See S. Bucovetsky, 'Asymmetric Tax Competition', 30 Journal of Urban Economics, at 167-181 (1991); and J.D. Wilson, 'Tax Competition with Interregional Differences in Factor Endowments', 21 Regional Science and Urban Economics, at 423-451 (1991)

24. See for example S. Peralta and T. van Ypersele, 'Factor Endowments and Welfare Levels in an Asymmetric Tax Competition Game', Journal of Urban Economics, at 258-274 (2005); and S. Peralta and T. van Ypersele, 'Coordination of Capital Taxation Among Asymmetric Countries', 36 Regional Science and Urban Economics, at 708-726 (2006). this gives rise to a negative spillover. ${ }^{25}$ The reduction in well-being of the foreigner when its investments are being taxed by the home government is not taken into account, such that the home government has a tendency to set a tax rate that is too high. Third, in the classical tax competition model, the total amount of capital is fixed; it only migrates between countries. When instead it is assumed that the total tax base can become either larger or smaller in response to changes in the effective level of capital taxation in the world, for example because individuals adjust their savings, it follows that the gains from tax coordination decrease. ${ }^{26}$ Increasing the average level of taxation now reduces the total tax base, which causes a reduction in tax revenue.

Until now we have focused on coordinating the full corporate tax system, tax base and rate, all harmonised. The expected gains from weaker forms of cooperation are much smaller. For example, when one tax instrument is not included in the agreement, competition tends to intensify on this instrument. An example is the attempt by the EC to coordinate only the tax base, leaving the decision on tax rates to the discretion of the individual Member States. Also, when some countries do not join the cooperation agreement, the gains for the remaining countries are reduced. ${ }^{27}$

Despite all caveats, the models and results discussed above show that under reasonable parameter values, tax competition leads to tax rates that are too low such that a coordinated increase to some degree can raise welfare. I will label this the strong result from the classical tax competition literature in the remainder of this article. Although the models discussed above are not tailormade to capture excessive tax planning by firms, or excessive tax-setting strategies by governments, this strong result does resonate in the public debate regarding these topics. ${ }^{28}$ The model describes optimal government behaviour in the case of a mobile tax base that moves to another country. This acts as a mirror image to models that study taxation in a closed economy where individuals being taxed just redirect their effort into activities that are taxed less heavily - that is, there is nothing 'excessive' or 'immoral' in the model, just individuals behaving optimally.

Besides this remark, the reader must realise that this strong result is an optimistic result. It is fundamentally based upon the assumption that the government intends to maximise welfare. When the government does not

25. See amongst others H. Huizinga and S.B. Nielsen, 'Capital Income and Profit Taxation with Foreign Ownership of Firms', 42 Journal of International Economics, at 149-165 (1997).

26. See amongst others I.W.H. Parry, 'How Large Are the Welfare Costs of Tax Competition?', 54 Journal of Urban Economics, at 39-60 (2003).

27. I will not pursue this discussion further here, but refer the interested reader to $\mathrm{H}$. Vrijburg, '50 Years of European Union Corporate Income Tax Harmonization Initiatives: Is Enhanced Cooperation the Solution?', in D.A. Albregtse and P. Kavelaars (eds.), Naar een Europese Winstbelasting? (2010)

28. See also J. Slemrod and J.D. Wilson, 'Tax Competition with Parasitic Tax Havens', 93 Journal of Public Economics, at 1265 (2009), for a similar remark. 
intend to maximise welfare, tax competition might in fact improve welfare. ${ }^{29}$

If the government does not have welfare in mind when it chooses its tax rate, it ignores the distortionary effect of the tax on welfare and hence chooses tax rates that are too high from a welfare perspective in the absence of competitive pressure. The government might for example be distracted from welfare by collecting revenue to finance projects that are valued highly by the politicians themselves but not necessarily by the citizens. Admittedly, this idea, which comes from the public choice literature on Leviathan governments by Brennan and Buchanan, adheres to a very dark view of government. ${ }^{30}$ On the other hand, it is often the case that government sets a target of maximising tax revenues from corporate taxes. One can understand such an approach when recognising that welfare might be a problematic concept to quantify such that aiming for maximum tax revenues might be an 'acceptable' simple heuristic that guides governments in practice. When this is the case, however, the natural state of government might well be to 'over-tax'. Tax competition constrains this natural state. A further shortcoming is that the discussion from Section 3 hardly appears anywhere in the classical tax competition literature. The models assume rather ad hoc that capital taxes should be used instead of this being a deliberate choice of the governments. This is a fundamental shortcoming. Governments can always use lump sum transfers to finance their expenditures. Distortionary taxes should be used only to achieve some other policy goal next to revenues. ${ }^{31}$ Labour taxes are used to redistribute income: tax those with a higher ability to earn income more than individuals with a lower ability. Excise taxes are used to internalise some externality, for example in the case of smoking and alcohol. From the same argument, corporate taxes are used not because they yield tax revenues but precisely because they assist in redistributing income (see the discussion on the backstop function in Section 3). So, besides not modelling excessive tax setting and tax planning, the papers discussed above do not model the contribution of corporate/capital taxes to the tax system. Therefore, the welfare losses of tax competition might not show up in eroding tax revenues, but in too little income redistribution. $^{32}$

In recent years, scholars have modelled more realistic corporate tax systems in which governments not only choose source-based capital tax rates, but can, for example, also manipulate the definition of the tax base by set-

29. See J. Edwards and M. Keen, 'Tax Competition and the Leviathan', 40 European Economic Review, at 113-134 (1996)

30. G. Brennan and J.M. Buchanan, The Power to Tax: Analytical Foundations of a Fiscal Constitution (1980).

31. See amongst others B. Jacobs, A Contribution to the Theory of the Marginal Cost of Public Funds (2013).

32. See H.W. Sinn, 'How Much Europe? Subsidiarity, Centralization and Fiscal Competition', 41 Scottish Journal of Political Economy, at 85-107 (1994) ting the fraction of capital costs that is tax-deductible. ${ }^{33}$ Furthermore, firms are allowed to shift not only investments but also profits across borders. Besides developing the model, empirical evidence is found that supports the tax competition hypothesis. ${ }^{34}$ However, despite these improvements, these models typically still do not address the issues raised in Section 3, and the corporate tax system is imposed rather ad hoc, which is common practice in the literature. The models are used to study questions related to the issue of replacing Separate Accounting with Formula Apportionment. ${ }^{35}$ Interestingly, profit shifting is (partly) prohibited under the latter system in the models used. Although not addressing the specific role of the corporate tax, the main finding of these papers is interesting: reducing opportunities to profit shifting does not lead to an unambiguous welfare gain. The following section will explore this topic a bit further as these models, or the arguments developed within these models, have been used for simulation studies.

\section{The Effect on the Welfare of States: Action Needed? Some Numbers from Simulation Studies}

In this section, I provide some numbers that give an idea of the potential benefits of tax coordination. After the so-called Bolkestein report by the EC in 2001, a number of simulation studies have been performed by two groups of economists. ${ }^{36}$ The first group is centred around the Danish economist Sørensen and the research institute Copenhagen Economics, while the second group is related to the Dutch Bureau for Economic Policy Analysis (CPB) using a model that is in part built upon an early version of the model used by Sørensen. ${ }^{37}$ To my knowledge the papers cited below are still the scientific frontier on this topic. ${ }^{38}$ Both groups of economists constructed an own Computable General Equilibrium model with considerable detail. Computable Gen-

33. See for an early approach, A. Haufler and G. Schjelderup, 'Corporate Tax Systems and Cross-Country Profit Shifting', 30 Oxford Economic Papers, at 123-131 (2001).

34. See M. Devereux, B. Lockwood \& M. Redoano, 'Do Countries Compete Over Corporate Tax Rates?', 92 Journal of Public Economics, at 1210-1235 (2008)

35. See amongst others N. Riedel and M. Runkel, 'Company Tax Reform with a Water's Edge', 91 Journal of Public Economics, at 1533-1554 (2007); S.B. Nielsen, P.R. Raimondos-Moller \& G. Schjelderup, 'Company Taxation and Tax Spillovers: Separate Accounting Versus Formula Apportionment', 54 European Economic Review, at 121-132 (2010); and T. Eichner and M. Runkel, 'Corporate Income Taxation of Multinationals in a General Equilibrium Model', 95 Journal of Public Economics, at 723-733 (2011).

36. European Commission, 'Company Taxation in the Internal Market, Commission Staff Working Paper, COM(2001) 582, 2001.

37. See P.B. Sørensen, 'Company Tax Reform in the European Union', 11 International Tax and Public Finance, at 91-115 (2004).

38. See Vrijburg, above n. 27, for a more detailed discussion. 
eral Equilibrium models make assumptions on the production process in the economy, the consumption preferences of consumers, the objective function of the government and the resource allocation across consumers. Furthermore, a whole range of taxes is introduced to study the effects of changes in these taxes on welfare. Typically, these models are too complex to be solved analytically, and hence simulations are used.

A first set of studies by Sørensen incorporates the main arguments from the tax competition literature discussed above into a model that is complex but analytically solvable. ${ }^{39}$ This is achieved by not modelling individual countries, but four aggregate country groups (the United Kingdom, Northern Europe, Continental Europe and the United States). He assumes that the government in each of these blocks intends to maximise welfare by deciding over two tax instruments (a tax on capital and a tax on labour), a lump sum transfer, a public good that enhances domestic productivity and a normal public good. Interestingly, Sørensen does allow for lump sum transfers, implying that the tax on capital income is motivated by something other than just revenue. This is achieved by modelling citizens who are heterogeneous in their wealth and earnings ability, introducing a redistributive motive for the government. Both the tax on capital and the tax on labour are used to redistribute.

Citizens supply labour and savings to the domestic labour market and international capital market, respectively. Both the total supply of labour and the total supply of capital are endogenous. Production occurs by combining domestically supplied labour with capital attracted from the international capital market and some fixed input. Part of the production process is owned by foreigners, and, likewise, some foreign production is owned by domestic citizens. The government taxes labour income (or consumption) and levies a sourcebased tax on the total return to capital (profits and normal return). The revenues are used to finance the transfers to all citizens, the previously mentioned productive public good and a normal public good. The equilibrium of the model is a so-called Nash equilibrium, where none of the countries wants to adjust its tax or expenditure policy given the choices made by the other governments.

This implies that all arguments mentioned in Section 3 are present in the model. To compute the welfare gain of tax coordination, the model parameters are chosen such that the equilibrium tax rates under tax competition equal the observed effective tax rates in the real world. In equilibrium, the (net) international spillovers are positive, implying too little redistribution under tax competition. Following this observation, Sørensen computes a small welfare gain from EU-wide coordination $(0.10-0.32 \%$ of GDP) that is asymmetric across countries and across the population; the poorest individuals

39. See P.B. Sørensen, 'The Case for International Tax Co-ordination Reconsidered', 31 Economic Policy, at 429-472 (2000); and P.B. Sørensen, 'International Tax Coordination: Regionalism Versus Globalism', 88 Journal of Public Economics, at 1187-1214 (2004). gain the most. ${ }^{40}$ The welfare gain comes from higher transfers to the poor financed by higher capital tax rates in the cooperating countries, which is possible because escaping the tax is more difficult for investors when a large number of countries raise their tax rate. Furthermore, the higher capital tax rates are used to finance a reduction in labour income taxes, which boosts labour supply. Competition in capital tax rates is partly replaced by more competition in productive infrastructure, but this effect is minor. The welfare gain obtained from this model should be compared with the estimated welfare effects of previous and anticipated EU action, which are in the range of $0.5-1.9 \%$ of GDP. ${ }^{41}$ The welfare gain computed by Sørensen is therefore at the lower end.

A second class of simulation studies adds more institutional detail: either all EU countries or all OECD countries are modelled. ${ }^{42}$ The price to be paid for this institutional detail is that government policy is exogenous (is changed from outside the model), as opposed to the model by Sørensen where government policy is endogenous (determined by optimal policy rules that are a function of the model parameters). This is a necessary restriction because strategic games between a large number of asymmetric players cannot be solved analytically. This is not an innocent assumption, because, typically, governments will respond to an exogenously imposed constraint by changing another tax instrument such that the previous policy goal can still partly be achieved via a detour. As opposed to the model discussed above, these more detailed models include a more fully fledged financial system where both bonds and equity are traded, two types of firms (domestic firms and MNEs with subsidiaries in all other countries). Two distinct channels now operate. Capital can be reallocated to circumvent capital taxes, as in the Sørensen model, but profit also can be shifted across countries such that the effective tax rates on capital are lowered (using both transfer pricing and debt financing). The authors have subsequently tried to match the tax parameters in the model as closely as possible to the observed tax policies within the EU.

Several reforms are studied in these detailed models. First, a minimum CIT rate of 33\%, the EU-average at the time of writing. ${ }^{43}$ The reform is budget-neutral, which is ensured by changing the labour income tax

40. More egalitarian countries gain more because they value the extra redistribution more, countries with a higher share of pure profits gain more because they raise more extra revenue, capital importers gain more because they benefit more from the reduction in the net interest rate.

41. See G. Nicodeme, 'Corporate Tax Competition and Coordination in the European Union: What Do We Know? Where Do We stand?', MPRA Working Paper No. 107 (2006).

42. Not discussed in this review owing to limited space, but certainly interesting as well are the papers by J. Brøchner, J. Jensen, P. Svensson \& P.B. Sørensen, 'The Dilemmas of Tax Coordination in the Enlarged European Union', Working Paper No. 1859 (2006); and Sørensen, above n. 37.

43. L. Bettendrof, J. Gorter \& A. van der Horst, 'Who Benefits from Tax Competition in the European Union', CPB Discussion Paper No. 125 (2006). 
accordingly. Six EU countries, at the time of the study, should have raised their tax rate to comply with this minimum rate. On average, welfare hardly changes, and GDP goes down by $0.1 \%$ owing to an increase in the marginal effective capital tax rate. This distorts capital investments into the countries that are forced to increase their tax rate. Thereafter, the authors study the case where all countries are forced to adjust their tax rates to the EU-average. In this case, there is no welfare gain: the gains of the winners are as large as the losses of the losers. There is slightly more investment, but GDP decreases owing to increases in the labour income tax. Typically, countries with a higher initial tax gain relative to countries with a low initial tax, implying that being forced to increase the distortionary corporate tax is painful.

A subsequent paper studies the introduction of a Common Consolidated Corporate Tax Base (CCCTB) within the previously mentioned model. ${ }^{44}$ The CCCTB defines common tax base rules and replaces Separate Accounting by a Consolidated Tax Base that prohibits profit shifting. The consolidated tax base is allocated to the different countries using a formula involving labour, capital and production. Countries with a narrow tax base are forced to broaden their tax base, and vice versa for countries with a broad tax base. Broadening the tax base typically leads to more revenues and a reduction in investment because capital is taxed more at the margin owing to base broadening. Narrowing the tax base leads to a reduction in tax revenues and more investments because of the reversed argument. Interesting for the present article is that welfare hardly changes by introducing the CCCTB (increase of $0.02 \%$ of GDP in the base case) because tax planning is replaced by real factor reallocation. From this, it can be concluded that the taxplanning activities do not substantially harm welfare in the model, whereas the factor reallocations do! To be precise, the authors state: '[...] transfer pricing alleviates the tax burden for MNEs, and is therefore good for growth'. A gain in tax compliance, assumed to be around $10 \%$ of tax revenues based on scarce empirical evidence, ensures that welfare does not deteriorate following the introduction of the CCCTB. Low-tax countries tend to gain from the CCCTB because MNEs shift production to these countries. In a number of follow-up papers using the same model, the conclusion that the CCCTB does not substantially increase welfare is found to be robust. ${ }^{45}$

The above discussion highlights a number of important conclusions. First, large Computable General Equilibrium models cannot find a substantial welfare gain from

44. L. Bettendorf, A. van der Horst \& H. Rojas-Romagosa, 'Will Corporate Tax Consolidation Improve Efficiency in the European Union?', Tinbergen Institute Discussion Paper No. 07-076/2 (2007).

45. See L. Bettendorf, A. van der Horst, R.A. de Mooij \& H. Vrijburg, 'Corporate Tax Consolidation and Enhanced Cooperation in the European Union', 31 Fiscal Studies, at 453-479 (2010); and L. Bettendorf, M.P. Devereux, A. van der Horst, S. Loretz \& R.A. de Mooij, 'Corporate Tax Harmonization in the European Union', 25 Economic Policy, at 537-590 (2010). See for further discussion Vrijburg, above n. 27. coordinative action in the EU. However, some remarks must be made. First of all, the studies by Sørensen do not allow for tax planning. The welfare gain comes from the strong tax competition result mentioned in the previous section, so undertaxation is resolved. This, however, is not the topic of this article. The models with more institutional detail do allow for multinational firms that engage in profit-shifting activities to lower their tax bill. However, besides being unable to find a welfare gain, these models lack a 'backstop function', implying that it is impossible to judge how either tax competition or tax coordination affects the redistributive function of the tax system; it just reports the sum of the change in economic distortions. But, as claimed in Section 2, when this is the true policy goal, why not just abandon the corporate tax altogether?

\section{Tax Competition Model with Tax Planning: Are Tax Havens Parasitic or Useful?}

We continue our search for the welfare costs of excessive company taxation practices with the discussion of two recent papers: Slemrod and Wilson (2009) show that 'excessive tax planning' lowers welfare, whereas Hong and Smart (2010) show that tax havens might raise welfare. ${ }^{46}$ I will discuss both and identify the crucial difference in assumption. Finally, I relate the result to the literature on preferential versus non-preferential tax regimes.

Similar to the classical tax competition model, Slemrod and Wilson model a large number of countries. As opposed to the classical tax competition model, firms are modelled slightly different, some are now allowed to engage in tax planning. Slemrod and Wilson assume that each unit of capital represents a firm. All firms are identical except for upfront costs that need to be incurred in order to be able to avoid taxes via a tax haven: the 'participation costs'. These tax havens are supposed to be small countries that supply 'concealment services' to firms. These concealment services can be used to underreport taxable income, be it legal or illegal. The price of these services depends on the demand for the services by firms: the more avoidance is demanded, the higher the price. One can interpret the sum of both the participation costs and the total amount paid for concealment services as the reward paid to the legal and accounting sector for computing the optimal tax strategy. Also, the instrument set of the government is widened. Besides choosing a tax rate, the government can now also invest in enforcing the tax code. For each firm that participates

46. Slemrod and Wilson, above n 28; and Q. Hong and M. Smart, 'In Praise of Tax Havens: International Tax Planning and Foreign Direct Investment', 54 European Economic Review, at 82-95 (2010). See for a further introduction into this discussion D. Dharmapala, 'What Problems and Opportunities Are Created by Tax Havens?', 24 Oxford Review of Economic Policy, at 661-679 (2009). 
in a tax haven, the share of taxable income that can be shielded increases when more concealment services are bought, whereas it declines when the government undertakes more enforcement activities.

Given all cost parameters, the tax rate and the level of enforcement decided on by the government, a number of firms (not all of them) decide to engage in excessive tax planning. A small thought experiment reveals that an increase in the statutory tax rate would lead to an increase in the demand for concealment services and an increase in the number of firms that engage in excessive tax planning. This is because the higher statutory tax rate makes participating in avoidance more attractive. The revenue effect of both more concealment and more avoidance must be compensated with a further increase in the tax rate. Compared with an otherwise identical classical tax competition model, the costs associated with these newly introduced tax-planning activities lower the effective rate of return on capital within the country. This results in an outflow of capital and a larger excess burden: welfare decreases. Note that compared with the standard tax competition model, the welfare costs in Slemrod and Wilson's model come from both a statutory tax rate that is too high and resources invested in activities that are intrinsically useless from a social point of view (tax planning). Preventing firms from using the tax havens would imply that the government could save on enforcement costs, firms could save on the expenditures into concealment services and the government would receive more tax revenues. These extra revenues would allow the government to slightly reduce the tax rate, which also reduces the total excess burden from taxation.

A second lesson from Slemrod and Wilson is that also partially eliminating tax havens is welfare-improving. ${ }^{47}$ This is because the decrease in the supply of concealment services will cause a higher price for these services such that the government can save on enforcement costs for obtaining the same revenue. The price of concealment services has a similar effect on firm choices as government enforcement spending. Furthermore, Slemrod and Wilson explain a new externality arising in such a model. Countries would jointly benefit from a coordinated reduction in enforcement activities; this would increase the price of concealment services, which would endogenously constrain tax planning. An individual country is too small to have an effect on this price, but jointly countries would have such an effect (a coordinated increase in the tax rate has a similar effect). All in all, it is worthwhile to reduce tax-planning opportunities through coordination.

The conclusion from Slemrod and Wilson (2009) conflicts with the conclusion from Hong and Smart (2010), who conclude that tax planning is welfare improving.

47. The process of partially reducing tax havens, and the strategy to follow, is an interesting research topic in itself. See M. Elsayyad and K.A. Konrad, 'Fighting Multiple Tax Havens', 86 Journal of International Economics, at 295-305 (2012), who show that removing tax havens might reduce welfare when it relaxes competition between the remaining tax havens.
Hong and Smart differentiate from the classical tax competition model by assuming that there are two types of capital, domestic and international. Domestic capital is owned by domestic entrepreneurs, whereas international capital is owned by the public. The key insight is that the government cannot observe the difference between the two (recognise a third-best approach) and therefore has to tax both the same. Such a constraint on the ability of the government to tax is often related to a political constraint, for example when the government cannot explain to the public that it partially refrains from taxing international firms. Besides this deviation from the classical tax competition model, a fundamental difference with respect to Slemrod and Wilson is the assumption that the government wants to redistribute from domestic entrepreneurs to workers. This introduces, in my opinion, the fundamental role of the corporate tax into the discussion: it assists in redistributing income. Furthermore, the government does not care inherently about the owners of international capital. In their own words: '[...] the corporate tax is a devise for domestic, not international redistribution, so that revenue losses due to income shifting have no direct effect on welfare'.

Domestic capital cannot escape taxation, whereas international capital can, and such an outflow of capital in part hurts domestic workers because they have less capital to work with, implying lower wages. This essentially clarifies their findings. The government is not after taxing international capital at all: it would rather leave it unaffected or even subsidise it. Hence, the government welcomes all opportunities for a reduction of the effective rate of taxation on international capital, while it can still levy a high tax on domestic entrepreneurs to finance transfers to the working population. Tax avoidance offers that opportunity. As a result of tax planning, the government can redistribute more from domestic entrepreneurs towards domestic labourers. ${ }^{48}$ In an extension, Hong and Smart consider some costs associated with tax planning and conclude that in this case some restrictions on tax planning might be needed. But still, a complete elimination is surely undesirable.

What can be thought about these two conflicting results? At first sight, the argument from Hong and Smart seems trivial. They model ad hoc a group of entrepreneurs that is immobile and relatively rich. Taxing this group to finance a transfer to the poor obviously raises welfare. But such a comment downgrades their fundamental insight that highlights an important deficiency in the classical tax competition model (and therefore in the model of Slemrod and Wilson). In this classical tax competition model, the government, in essence, wants to tax all firms the same as all firms are inherently identical. Note also that Slemrod and Wilson model homogeneous firms that only differ by some unexplained random cost parameter that makes some firms

\footnotetext{
48. This is not a pure Pareto improvement as domestic entrepreneurs would be better off with a lower tax on their earnings. However, the redistributive preferences of the government more than compensate this loss.
} 
better in tax planning than others. Still, if the government had perfect information, it would like to tax all these firms using the same uniform capital tax to obtain the desired level of tax revenue (assuming that a lump sum transfer is not available). Therefore, all anomalies that imply higher statutory tax rates or less revenue from this uniform collection of firms will lead to lower welfare. Whereas Hong and Smart model an ad hoc equity argument leading to a seemingly straightforward result, Slemrod and Wilson assume that all firms are identical, and by doing so assume that the government is indifferent towards taxing the various firms from redistributive arguments (interpreting the public good as redistribution in this case). On the other hand, Hong and Smart only slightly address the central argument from Slemrod and Wilson: the resources misused for tax-planning activities. Also, Hong and Smart take an extreme position in the availability of avoidance technology: only the international firms can avoid. This is in contrast to Slemrod and Wilson, who assume that all firms have the same probability to avoid.

These two models show that the welfare effects of excessive company taxation practices are not straightforward, but depend crucially on two questions. First, the magnitude of resources lost in the process of tax planning. When the government really should intend to tax firms at a certain level, activities that undermine this are just a social loss. But one should also keep in mind that enforcing tax codes might cost valuable resources, and the alternative use of these resources should be taken into account. Next to that, an equally important question is, how large are the marginal social gains from taxing the profits of a particular firm? When all firms are identical, these gains are uniform across firms, and the optimal tax should be uniform as in Slemrod and Wilson. When there are two types of firms, some domestically owned and immobile and some internationally owned and mobile, the marginal social gain is positive on the first group and maybe even negative on the second group, as in Hong and Smart. Real-world marginal social benefit functions will be far more complex. Firms cannot easily be classified as either domestic or international. Some of the international firms might be owned partially by rich domestic citizens, while other small seemingly domestic firms might be owned by international investors. Furthermore, more dimensions of heterogeneity might exist besides ownership and mobility. For example, the ability to conceal tax payments might not be exclusive to the international group. A simple policy conclusion is that when tax avoidance becomes too widespread (i.e., it extends to the small domestic firms), no firm will pay taxes anymore, and tax avoidance certainly lowers welfare because it becomes impossible to tax capital. The intermediate cases require a further investigation.

A central thought in the above discussion is that the corporate tax is not a tax on a uniform group of firms. It might therefore be optimal to differentiate the tax system between different subgroups. Such an idea is not new. Besides Hong and Smart, a number of articles write about the desirability of preferential tax regimes for obtaining tax revenue. A key finding here is that preferential regimes are to be preferred under some assumptions. When the corporate tax base can be separated into two, or more, homogeneous groups with each an own degree of mobility, it has been shown that it is optimal to have a lower tax rate on the more mobile tax base. ${ }^{49}$ This is just an application of the Ramsey inverse elasticity principle. When the government is restricted by international rules to set a uniform tax rate, it is forced to tax both suboptimally. However, when one tax base is mobile between countries while the other is immobile internationally (although domestically elastic), this conclusion might no longer hold. ${ }^{50}$ The equilibrium in such a tax game results in a low tax on the mobile base and a high tax on the immobile base, and this latter tax is not affected by tax competition considerations at all. It can now be shown that it is optimal to impose a uniform tax on both bases. The immobile base causes the uniform tax to be above the low rate, yielding more revenue on the mobile tax base. The revenue loss from the relatively low uniform tax on the immobile base is partially compensated by an increase of the immobile tax base (e.g., a lower capital tax would induce domestic citizens to save more).

However, it must be recognised that these articles focus solely on the revenue-raising potential of the tax system. They do not attempt to explain the fundamental role of the corporate tax in the tax system, do not model the potential misallocation of resources into tax planning and therefore stay short of answering the research question formulated in the introduction of this article. The articles just try to answer the question whether preferential tax regimes help in raising revenue in an efficient way, an issue that I mentioned is not at the heart of the problem.

\section{Conclusion}

This article explored the question of whether excessive company taxation practices harm welfare. The public discussion on this topic seems to be dominated by emotions and associative thoughts related to 'fair' taxation, whatever that may be. Within such a mindset, it seems natural to demand a substantial tax payment from multinational enterprises operating within the boundaries of a country. This article discussed some crucial points that are completely missing from the debate. Contrary to the commonly held beliefs, the article showed that economists have not yet come to a clear conclusion.

49. See Keen, above n. 18.

50. See E. Janeba and W. Peters, 'Tax Evasion, Tax Competition and the Gains from Non-Discrimination: The Case for Interest Taxation in Europe', 109 Economic Journal, at 93-101 (1999). A more general treatment is given in E. Janeba and M. Smart (eds.), 'Is Targeted Tax Competition Less Harmful Than Its Remedies?', International Tax and Public Finance, 10, at 259-280 (2003). 
First, a consistent conceptual framework of thought is absent in the public debate. Arguments from the economic literature suggest that the government should only use the corporate tax when the government has a hard time observing individual capital income and finds it difficult to distinguish between capital and labour income. As such, the corporate tax serves as a 'backstop' to preserve the redistributive function of the individual income tax. Opinion leaders seem unaware of the existence of a discussion regarding the economic arguments surrounding the corporate tax. Instead, this discussion is replaced by a simple, and fundamentally flawed, heuristic: the corporate tax is important because it generates tax revenue from firms that otherwise has to be collected from labourers and consumers. This heuristic is fundamentally flawed also because the corporate tax is paid by labourers and consumers and revenue is not the argument for having a corporate tax; a lump sum levy can be used for such a policy goal.

Second, the strong result from the tax competition literature echoes the public discussion. This strong result, which appears in most articles using the classical tax competition model, claims that tax rates on mobile tax bases tend to be too low from a social point of view. In these models, action by a central authority is needed to ensure that social welfare is increased. However, the classical tax competition model is too simplistic to cover excessive company taxation practices, which is the subject of this article. Furthermore, its conclusions only hold when one has a very positive view of government. Finally, even detailed simulation studies cannot find a substantial welfare gain from coordinated action by a central authority (e.g., the EC).

Third, some recent articles have discussed excessive company taxation practices in a more detailed model coming to opposing views. When one assumes that all firms are inherently identical and when the ability to evade or avoid taxes is randomly distributed over these firms, avoidance surely reduces welfare. However, when one assumes that firms are heterogeneous and that the government wants to tax some firms more than others from a redistributive argument, and when the ability to evade or avoid is negatively related to this redistributive argument, tax planning might increase welfare.

Academic economists are expected to come to the most objective conclusion possible. For the subject of this article, the welfare effects of excessive company taxation practices, the objective conclusion is that we do not know and the most important question is still up in the air: What is the size of resources used in tax planning compared with the welfare gain (or loss) that such behaviour yields for the economy as a whole by creating an effective tax system that is closer to (further from) optimal than the current legal system? Until this question is answered appropriately, my advice would be: do not rush into anything that cannot be easily undone. 